\title{
Measuring the Impact of Some Macroeconomic Variables on the Stock Price Index in the Iraq Stock Exchange for the period (2006-2015)
}

\author{
${ }^{1}$ Khalil Ghazi Hassan, ${ }^{2}$ Wafaa Sabah \\ ${ }^{1,2}$ College of Management and Economics, University of Duhok, Kurdistan Region, Iraq
}

\begin{abstract}
This study aims at measuring the impact of some macroeconomic variables on stock prices index in the Iraqi Stock Exchange (ISX) for the monthly data from January 2006 to December 2015 based on (121) observations using the ARDL model. Results indicated that the stock price index of Iraq Stock Exchange (ISX) and macroeconomic variables are co-integrated and a long-run relationship exists between them. The long-run coefficients suggested that the consumer price index (CPI) and money supply (M2) had a negative effect while the Interest-Rate-Current Account (Over Draft) (DR) had a positive effect on the stock prices index. However, the variable exchange rate (EX) did not show significant effect on the stock prices index
\end{abstract}

Keywords: Iraq , Stock Price Index , Co-integration, autoregressive distributed lag (ARDL) bounds test, Unrestricted Error Correction Model (UECM).

\section{Introduction}

The stock market is an important financing tool for economic activity. Due to the economic development and the increasing demands of consumers and producers, demand on capital has increased although capital is already scarce in most developing economies. Therefore, capital investors resort to banks and stock markets that transfer cash balances from units that are characterized by financial surplus to deficit units. In this way, savings are mobilized and investors are prepared to create productive capacities that serve the economic development process. In the context of global competition, every country works to establish a stock market and contributes to its development by developing its administrative, regulatory, and legislative aspects besides other. Countries also

Academic Journal of Nawroz University

(AJNU) Volume 8, No 4 (2019).

Regular research paper : Published Oct 2019

Corresponding author's e-mail : Khalil.ghazi@gmail.com

Copyright (C2018 ${ }^{1}$ Khalil Ghazi Hassan, 2 Wafaa Sabah.

This is an open access article distributed under the Creative

Commons Attribution License. diversify financial instruments to achieve an economic efficiency that guarantees economic growth rates that promote the economy and development. A number of factors indicate to the investors if they will obtain high or low returns as a result of their investments in stocks. These factors are economic variables and any change in those variables affects the stock prices. In order to rebuild a strong economy, Iraq needs a wellfunctioning financial system which is the cornerstone of a strong economy and which certainly includes a stock market.

\subsection{The Importance of the Study}

This study acquires its importance from the fact that it is an attempt to shed light on the role of the stock price index in the Iraqi Stock Exchange market to the economic growth and activity. As the capital markets are an important and complementary part of the economic activity, it was necessary to study the capital markets and the development of their performance, and to identify what the macroeconomic variables generated from the effects and implications on the 
performance of the stock price index, to the extent that contributes to the introduction of new and important information to a number of stakeholders in the capital markets, such as government agencies, investors and researchers in this area.

\subsection{The problem of study}

The study problem can be stated through the following questions:

- Is there an impact of macroeconomic variables represented i.e.: consumer price index , exchange rate, money supply, and interest-rate-current account (over draft) on the stock price index ?

- Is there a long-run and short -run relationship between macroeconomic variables and the stock prices index?

\subsection{Hypothesis of the study}

The hypotheses formulated for this study are;

- The Consumer Price Index (CPI) has a significant and inverse effect on the stock price index.

- The exchange rate has a positive but non-significant effect on the stock prices index.

- Money supply has a significant and inverse effect on the stock price index.

- The interest-rate-current account (over draft) has a positive and significant effect on the stock price index.

\subsection{Objectives of the study}

The objectives of this study are to:

- Identify the general of stock price index.

- Identify the relevant macroeconomic variables in the stock price index.

- Measure and analyze the impact of some macroeconomic variables on the stock price index in the Iraqi stock exchange.

\subsection{The scope of the study}

For the purpose of achieving the objectives of the study the Iraq Stock Exchange was selected as a sample of the study. A quantitative and descriptive approach was used to investigate the relationship between macroeconomic variables and the stock market for the study sample (the Iraq Stock Exchange) for the period from January 2006 to December 2015. The research was divided into two sections. The first section dealt with the theoretical framework that covers the literature review and a brief account of the evolution of stock index of the Iraq Stock Exchange. The second section discusses the data analysis and methodology of the study and the discussion of the results and was concluded with the most important conclusions.

\section{Theoretical Framework}

\subsection{Literature review}

The study of (Khalid, Khan, 2017) showed the effect of interest rate, exchange rate, and inflation rate on the market performance of Pakistan Stock Exchange using the annual time series data for the period (1991-2017). He used the ARDL model to investigate the impact of these variables on the KSE-100 index in the short and long term. The results of his study showed an inverse relationship between the interest rate and the market index and a direct relationship between exchange rate and inflation rate. In his study, (Gay,2008 ) used monthly data for his study sample consisting of three economies (Brazil, Russia, India and China), for the period from March 1993 to June 2006 using the exchange rate and the price of oil as explanatory variables and the stock market index as a dependent variable, using the Box-Jenkins model and the DickeyFuller test and the study concluded that the price of oil and exchange rate had no positive effect on returns of stock markets in the study sample.

Based on the (S \& P500) index as a dependent variable and the monthly data for the variables of interest rate and industrial production for the period from January 2001 to April 2008, (Ngoc \& Hussainey, 2009) found 
that industrial production showed a positive and significant relationship with the Vietnamese stock price index and interest rate shows no significance relationship while the stock prices showed negative relationship.

The study of (Patel, 2012) concerning the macroeconomic determinants and their impact on the performance of the Indian stock market, used monthly data for a time series for the period January 1991 December 2011. The researcher relied on two indicators of the Indian stock market (Sensex and Nifty S\&P CNX) and used the vector auto regression model VAR, Johansson test and Dickey -Fuller test in the analysis. The study concluded that the interest rate had a negative effect on stock indices while inflation, industrial production, monetary supply, and the prices of gold, silver, and oil showed positive and significant relationship to stock market indices.

In a study titled " Impact of Macroeconomic Variables on the Stock Market Prices of the Stockholm Stock Exchange (OMXS30) " , (Talla, 2013) used monthly data for the period from January 1993 - December 2012. The results of the study showed that the inflation rate in addition to the exchange rate had a significant negative impact on the stock prices of the Stock Exchange (OMXS30). Moreover, the relationship between interest rate and stock prices was negative and non-significant while monetary supply was positive and significant.

The study by (الزبيدي ،والمعموري) investigated the impact of exchange rate fluctuations on the Iraq exchange stock prices index for the period (2005-2011) and showed a two directional causality relationship between the variables of the study, namely, exchange rate and price index. The study showed that exchange rate fluctuations had different effects and different trends on the general stock prices indices from one month to another during investigated period of their study.

Barkat et al. (2016) studied the long-term relationship between the stock markets and macroeconomic factors in two emerging economies (Egypt and Tunisia) using monthly data covering a period of 17 years from January 1998 to January 2014. The variables included in the analysis were the money supply, consumer prices index, exchange rate and, interest rate. The results indicated a causal relationship in Egypt between market index and consumer price index CPI, money supply, exchange rate, and interest rate. The same goes for Tunisia except for consumer price index. Results also indicated that four macroeconomic variables are co- integrated with the stock market in (Egypt and Tunisia.)

Chia and Lim (2015) examined the long-term relationship between the Malaysian stock market and selected macroeconomic variables, including inflation, industrial production, money supply, interest rate and exchange rate over the period (1980:Q1 to 2011:Q3) using autoregressive distributed lag (ARDL). The longrun coefficients suggested that the Malaysian stock prices were negatively influenced by inflation and positively influenced by money supply and interest rates. The results from the error correction mechanism reveal that real returns were Granger caused by real money growth and real interest rates. When the exchange rate was included in the estimation, significant relationship were observed and this implied that exchange rate fluctuations can cause movement in stock prices. This study indicated that the exchange rate is a proper determinant that has explanatory power over stock returns.

Al-Batal and Mutar estimated the effect of inflation on the earnings of sectors shares in the Iraqi Exchange Market, using ARDL and Autoregressive models. The results showed an inverse and equilibrium long-run 
relationship between them in the banking, insurance, investment, and tourism sectors and stock price index, while an inverse and short-run relationship was found with all the aforementioned sectors except tourism. (البتال ،ومطر، 2017).

The study of Al-Nayef (النيف، 2018) aimed to test the dynamic relationship between the macroeconomic variables and the general index of the Amman Stock Exchange and a number of macroeconomic variables which included (money supply, inflation and industrial production index), which used the co-integration methodology, for the period from January 2000 to October 2016. The study concluded a long-term equilibrium relationship between the index of the stock market and the inflation rate, the index of industrial production. The study also pointed to a one-way causal relationship to all macroeconomic variables in the short term.

It is clear from the previous literature that some macroeconomic variables affect the stock prices index in the performance of the international stock market. It's obvious that all presented papers measured the relationship between macroeconomics indicators (monetary or fiscal) and price index stock in different stock markets. They utilized similar models in the estimation approach.

We also used some selected macroeconomics to estimate their effect on the stock price index in Iraqi stock exchange. However, unlike them, we utilized both variables, monetary as well as fiscal. In addition, we used a different period of time (January 2006December 2015), and a new standard economic approach (Auto regressive Distributed Lag (ARDL).

\section{Data Analysis}

The stock market index as in Figure (1), shows the evolution of the stock price index for the period (20042016).
Figure (1) shows that there was an improvement in the stock price index in 2007 with a growth rate of $(36.78 \%)$ compared with the previous year. This was due to the growth of the sectors index, where the index rose for

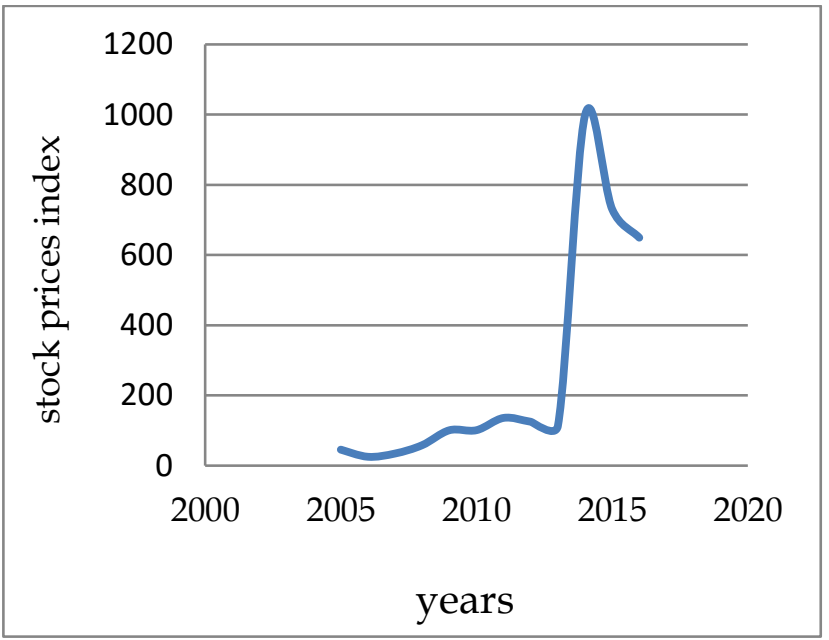

Figure (1) Evolution of the of Stock Price Index in the Iraq Stock Exchange in the Period (2004- 2016)

Source: - Prepared by the researcher depending on the reports of the Iraq Stock Exchange 2004-2016, and the annual reports of the movement of trading of the Iraqi Securities 2005-2016.

the four sectors listed in the Iraq Stock Exchange (i.e. Services, Investment, Hotels and Tourism, and Industry), (Iraqi Securities Commission, 2011). In the three consecutive years (2012, 2013, and 2014), the general stock price index recorded (125.02, 113.15, $998.21)$ points, a decline of $(-8.01 \%,-9.5 \%,-18.69 \%)$ respectively. The decline in the index during 2016 reached to (649.47) points, a decrease of (-23.21\%). The reason for the decline was due to the impact of adverse economic conditions in Iraq following 2014, because of the ISIS terrorist group's occupation of a number of cities in Iraq negatively impacted the national economic activity, and caused a global decline in oil prices in mid-2014, which led to the deterioration and decline of capital indicators. (Iraqi Stock Exchange Report, 2016). The top ten companies in the Iraqi capital market in 2016 played a significant major role in moving the national economy in spite of all the difficulties faced by 
the Iraqi economy since 2004. Until nowadays, these first companies were vital to enhancing the activity of the Iraqi capital market. The Bank of Mosul is first on the list of trading where the volume of its trading amounted to (76.2) billion Dinars representing (17.8\%) of the total trade volume as shown in the table (1). The banking sector in the list includes nine companies, while the industrial sector includes one company as shown in table (1).

Table (1): The Highest 10 Ranked Traded Companies in Terms of Trading Volume in 2016

\begin{tabular}{|l|l|l|}
\hline Name of company & $\begin{array}{c}\text { Volume of } \\
\text { trading } \\
\text { Million ID }\end{array}$ & $\begin{array}{l}\text { Percentage } \\
\text { of total }\end{array}$ \\
\hline Bank of Mosul & 76160.8 & 17.8 \\
\hline Baghdad for soft drinks & 43251.8 & 10.1 \\
\hline United Investment Bank & 38723.8 & 9.1 \\
\hline Bank of Baghdad & 29787.9 & 7 \\
\hline $\begin{array}{l}\text { Middle East Investment } \\
\text { Bank Salaam }\end{array}$ & 27645.1 & 6.5 \\
\hline $\begin{array}{l}\text { Dar es } \\
\text { Investment Bank }\end{array}$ & 16544.3 & 4.3 \\
\hline $\begin{array}{l}\text { Commercial Bank of } \\
\text { Iraq }\end{array}$ & 426788.1 & 3.9 \\
\hline Gulf Commercial Bank & 16167.4 & 3.8 \\
\hline Elaf Islamic Bank & 15117.4 & 3.5 \\
\hline Sumer Commercial Bank & 14446 & 3.4 \\
\hline Total ten companies & 296305.0 & \\
\hline $\begin{array}{l}\text { Total trading of all } \\
\text { sectors }\end{array}$ & & \\
\hline Sore Ans & & \\
\hline
\end{tabular}

Source: Annual report on the movement of trading of the Iraqi market for securities in 2016.

In second place on the list of trade volume was the company of (Baghdad for soft drinks), and the volume of its trading reached (43.3) billion Dinars, $(10.1 \%)$ of the total volume, and the figure illustrates the ratio of trading in the stock market for the top 10 companies and shows that the first place was for (Mosul Bank) by $(17.8 \%)$ of the total volume of trading, while the second place was for (Baghdad for soft drinks) and by (10.1\%). Third place was for the United Bank with (9.1\%) of the total volume of trading.

As for the 10 most traded companies in terms of the number of stocks traded for the year 2016, the Bank of Mosul ranked first in terms of the number of shares traded in the Iraqi capital market as the number of shares traded reached (197.6) billion shares, $(21.5 \%)$ of the total. The table below shows the values and number of shares traded and the percentage of trading of the total of the top ten companies as follows:

Table (2): The Highest (10) Ranked Traded Companies in Terms of the Number of Shares Traded in 2016

\begin{tabular}{|l|l|l|}
\hline Name of company & $\begin{array}{l}\text { Number of } \\
\text { shares In ID }\end{array}$ & $\begin{array}{l}\text { Percentage } \\
\text { of total }\end{array}$ \\
\hline Bank of Mosul & 197573.9 & 21.5 \\
\hline United Investment Bank & 175729.5 & 19.2 \\
\hline $\begin{array}{l}\text { Dar es Salaam Investment } \\
\text { Bank }\end{array}$ & 127528.2 & 13.9 \\
\hline $\begin{array}{l}\text { Middle East Investment } \\
\text { Bank }\end{array}$ & 70746.4 & 7.7 \\
\hline Elaf Islamic Bank & 45150.5 & 4.9 \\
\hline $\begin{array}{l}\text { Real estate commercial } \\
\text { bank }\end{array}$ & 39136.2 & 4.3 \\
\hline Gulf Commercial Bank & 38658.8 & 4.2 \\
\hline Bank of Baghdad & 36134.1 & 3.9 \\
\hline Bank of Babil & 32595.8 & 3.6 \\
\hline Baghdad for soft drinks & 16930.6 & 1.8 \\
\hline Total ten companies & 780184 & \\
\hline Total trading of all sectors & 917542.4 & \\
\hline Sorce Ant & & \\
\hline
\end{tabular}

Source: Annual report on the movement of trading of the Iraqi market for securities in 2016.

The above table illustrates that the share of the Bank of Mosul ranked first, and its traded shares amounted 
(197573.9) billion shares which represent $(21.5 \%)$ of the total shares while the United Bank came in second with shares traded at (175729.5) billion shares which represent (19.2\% ) of the total. The third place was for Dar AL-Salaam Investment Bank, the number of shares traded reached about 127528.2 billion shares which represent $(13.9 \%)$ of the total number of shares.

\section{Data and Methodology}

The purpose of this study is to investigate the impact of economic variables on the stock price index in the Iraq Stock Exchange. Table (3) shows the characterization of the economic variables used in the study in addition to the symbols of those variables.

Table 3: Description of Data

\begin{tabular}{|l|l|l|}
\hline $\begin{array}{l}\text { Name of } \\
\text { Variables }\end{array}$ & $\begin{array}{l}\text { Symbol } \\
\text { Used }\end{array}$ & Proxy Used \\
\hline $\begin{array}{l}\text { Consumer } \\
\text { Index }\end{array}$ & CPI & $\begin{array}{l}\text { Consumer price index } \\
\text { computed on the base year } \\
2007\end{array}$ \\
\hline $\begin{array}{l}\text { Money } \\
\text { Supply }\end{array}$ & M2 & $\begin{array}{l}\text { Money supply (M2) in local } \\
\text { currency Billion dinars }\end{array}$ \\
\hline $\begin{array}{l}\text { Exchange } \\
\text { Rate }\end{array}$ & EX & $\begin{array}{l}\text { The exchange rate is the end } \\
\text { of the period and is } \\
\text { denominated in local } \\
\text { currency against the US } \\
\text { dollar. }\end{array}$ \\
\hline $\begin{array}{l}\text { Interest } \\
\text { Rate }\end{array}$ & $\mathrm{R}$ & $\begin{array}{l}\text { Interest-Rate-Current } \\
\text { Account (Over Draft) in IQD }\end{array}$ \\
\hline $\begin{array}{l}\text { Stock } \\
\text { Indices }\end{array}$ & Index & $\begin{array}{l}\text { The closing price of the } \\
\text { stock price index }\end{array}$ \\
\hline
\end{tabular}

The methodology used in this study was the Auto Regressive Distributed Lag (ARDL) method developed by Pesaran (1997), Shinad (1998) and Pesaran et al (2001). This approach is one of the standard models used in the integration test using Bounds test, which differs from other approaches for integration tests
(End and Granger 1987), Johansen (1988) and (1990) Johansen-Juseliue) in that bounds testing approach to integration can be used in the ARDL methodology and without the limitation of using a time series with same degree whether the time series was a stable time series at $1(0)$ or an integrated series of the degree class 1 (1), but the only requirement is that the time series are not integrated at 1 (2) or higher.

Pesaran et al (2001) presented a new approach to test the extent to which the equilibrium relationship between the variables used in the model was achieved under the model of unrestricted error correction (Good, 29). This method is called bounds test approach, and in our model we have taken the logarithmic equation of the State of Iraq Agencies:

$$
\begin{aligned}
\Delta \text { Lindex }=\mathrm{la}_{\mathrm{o}}+ & \sum_{\mathrm{t}=1}^{\mathrm{r}} \mathrm{B}_{1} \Delta \operatorname{lindex}_{\mathrm{t}-1}+\sum_{\mathrm{i}=1}^{\mathrm{r}} \mathrm{B} 2 \Delta \mathrm{lcpi}_{\mathrm{t}-1} \\
& +\sum_{\mathrm{t}=1}^{\mathrm{r}} \mathrm{B}_{3} \Delta \mathrm{lEx}_{\mathrm{t}-1}+\sum_{\mathrm{t}=1}^{\mathrm{r}} \mathrm{B}_{4} \Delta \mathrm{l} \mathrm{M}_{2 \mathrm{t}-1} \\
& +\sum_{\mathrm{t}=1}^{\mathrm{r}} \mathrm{B}_{5} \Delta \mathrm{lR}_{\mathrm{t}-1}+\emptyset_{1} \operatorname{lindex}_{\mathrm{t}-1} \\
& +\emptyset_{2} \mathrm{lcpi}_{\mathrm{t}-1}+\emptyset_{3} \mathrm{lEx} \mathrm{E}-1+\emptyset_{4} \mathrm{lM}_{2 \mathrm{t}-1} \\
& +\emptyset_{5} \mathrm{lR}_{\mathrm{t}-1}+\varepsilon_{\mathrm{t}} \ldots \ldots \ldots . . .(1)
\end{aligned}
$$

Where $a_{o}$ represents the constant limit, L represents the natural logarithm of the study variables, B1, B2, B3, B4 and B5 represent the elasticity's in the short term, $(\varnothing 1$, $\emptyset 2, \quad 0 \quad \ldots \ldots . \emptyset 5)$ represent long-term elasticities, (r) represent the number of optimal time delay times for the model, et is the (random error limit),and( $t$ ) represents time.

In the ARDL model, the first of these steps are to test the root of the unit, time series stability and determine the degree of co-integration of the time series in whether each series was of 0 (1) or 1 (1) degree .

The test showed that the null hypothesis has a unit root and that the time series is not stationary. When the calculated value of the unit root test is smaller than its 
critical value, the null hypothesis is rejected and the alternative hypothesis is accepted (العنيزي, 2015).This means that a long-run equilibrium relationship exists between macroeconomic variables of the model. We use the Dicky Fuller and Phillips-Peron test to detect the degrees of the time series and test if there is a longterm equilibrium relationship between the model variables. If a long-term equilibrium relationship exists we move on to estimating parameters in the long term besides estimating variables in the short term. A longterm equilibrium relationship between the independent variables and dependent variable is determined through the bounds test developed by (Pesaran et al., 2001), which is based on the ( F ) test (Wald test ),through which the null-hypothesis is tested. The null hypothesis states that there is no co-integration between the variables. In contrast, the alternative hypothesis states that a co-integration exists between the variables of the study in the long term. The hypotheses are formulated as follows:

Ho: $\mathrm{B} 1=\mathrm{B} 2=\mathrm{B} 3=\mathrm{B} 4=\mathrm{B} 5=0$, there is no common integration between variables in the long run.

In contrast, the alternative hypothesis is : $\mathrm{H} 1: \mathrm{B} 1 \neq \mathrm{B} 2 \neq$ $\mathrm{B} 3 \neq \mathrm{B} 4 \neq \mathrm{B} 5 \neq 0$, there is a common integration between long term variables .

After the Wald test is carried out, the calculated F will be compared with the critical values of the minimum limits 1 (0) and the upper limits 1(1), following by Pesaran et al. (2001), at significant limits indicated for the co-integration test. If the value of the calculated $(\mathrm{F})$ is greater than the upper critical value, there is a longterm equilibrium relationship between the variables and co-integration between the variables of the model exists. However, if the calculated F value is less than the lower critical value, there is no long-term equilibrium relationship between the variables of the study and the null hypothesis can not be rejected as there is no co- integration and thus the alternative hypothesis is rejected. If the calculated $(\mathrm{F})$ lies between the two critical values, the results are inconclusive (2015

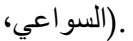

\subsection{Empirical Results}

The estimation of the effect of the independent variables in the stock price index is tested using the following tests.

\subsubsection{Unit Root}

Table (4) shows that the time series of the index of stock prices index (INDEX) of the Iraq Stock Exchange is stable at the first level (constant and a constant trend). The time series of the variables Consumer Price Index (DCPI), exchange rate (DEX) ) and the interest - rate current account (over draft) (DR) contain the unit root which means the of the null hypothesis is accepted and the alternative hypothesis is rejected as the value of calculated ( $t$ ) was less than the critical value at a significant level of $(1 \%, 5 \%$, and $10 \%)$ at all levels with both a constant and a general trend and no constant and general trend and this indicates acceptance of the null hypothesis that the existence of the unit root and rejection of the alternative hypothesis. However, after taking the differences of the first of the three levels, the calculated (t) was found smaller than the critical values at a significant level of $(1 \%, 5 \%$ and $10 \%)$. This lead to the rejection of the null hypothesis and acceptance of the alternative hypothesis which states that there is no unit root as shown in table (4).

\subsubsection{Testing for Serial Correlation}

After we tested the root of the unit and ensuring that there are no unstable time series, we proceeded to the diagnostic tests to determine if the model passes the standard tests and have no standard problems affecting the accuracy of the test results by using the (BreuschGodfrey Serial Correlation LM Test) instead of using (DW- STATISTICS). The results of the test in Table (5) 
show that the estimated model is free of serial correlation in the study series where the probability Source: Outcome from Eviews10 value is at (0.1023). Therefore, we accepted the null hypothesis that the residuals have no serial correlation problems within the error limit. To validate this result with no variance difference as shown in table (5).

Table 5: Results of the Breusch-Godfrey test

we determine( F) using the (Heteroskedasticity Test: Arch) which was (0.2146) which means that it is greater than $5 \%$, leading us to accept the alternative hypothesis that indicates the homogeneity of residues

4.1.3

In

\begin{tabular}{|l|l|}
\hline Prob & F- statistic \\
\hline 0.1023 & 2.330076 \\
\hline
\end{tabular}

Lag length selection order to

Table 4: The ADF-PP Test Results

\begin{tabular}{|c|c|c|c|c|c|c|c|}
\hline \multicolumn{4}{|l|}{ PP } & \multicolumn{4}{|l|}{$\mathrm{ADF}$} \\
\hline level & NONE & $\begin{array}{l}\text { Trend } \\
\text { and } \\
\text { intercept }\end{array}$ & Intercept & NONE & $\begin{array}{l}\text { Trend and } \\
\text { intercept }\end{array}$ & Intercept & Var \\
\hline \multirow[t]{2}{*}{ (1) 0} & $-1.083038^{(6)}$ & $-4.000593^{(1)^{*}}$ & $-3.582912^{*}{ }^{*} 1($ & $-1.477426^{(0)}$ & $-4.334634^{*} * 1($ & $-3.841149^{(1)^{*}}$ & INDEX \\
\hline & $\begin{array}{l}-1.943540^{(*)} \\
-1.614941^{(* *)}\end{array}$ & $\begin{array}{l}-3.448021^{(*)} \\
-3.149135^{(* *)}\end{array}$ & $\begin{array}{l}-2.885863^{(*)} \\
-2.579818^{(* *)}\end{array}$ & $\begin{array}{l}-1.943540^{(*)} \\
-1.614941^{(*)}\end{array}$ & $\begin{array}{l}-3.448348^{(*)} \\
-3.149326^{(* *)}\end{array}$ & $\begin{array}{l}-2.886074^{(*)} \\
-2.579931^{(* *)}\end{array}$ & $\begin{array}{l}\text { Test } \\
\text { critical } \\
\text { values }\end{array}$ \\
\hline \multirow[t]{2}{*}{ 1(1) } & $-11.06421^{(1) *}$ & $-11.00949)^{*} 1($ & $-11.05722^{(1)^{*}}$ & $-11.06409^{(0) *}$ & $-11.00934^{(0)^{*}}$ & $-11.05702^{(0)^{*}}$ & $\mathrm{D}(\mathrm{CPI})$ \\
\hline & $\begin{array}{l}-1.943563^{(*)} \\
-1.614927^{(*)}\end{array}$ & $\begin{array}{l}-3.448348^{(*)} \\
-3.149326^{(* *)}\end{array}$ & $\begin{array}{l}-2.886074^{(*)} \\
-2.579931^{(*)}\end{array}$ & $\begin{array}{l}-1.943563^{(*)} \\
-1.614927^{(*)}\end{array}$ & $\begin{array}{l}-3.448348^{(*)} \\
-3.149326^{(* *)}\end{array}$ & $\begin{array}{l}-2.886074^{(*)} \\
-2.579931^{(* *)}\end{array}$ & $\begin{array}{l}\text { Test } \\
\text { critical } \\
\text { values }\end{array}$ \\
\hline \multirow[t]{2}{*}{$1(1)$} & $-9.441035^{(6) *}$ & $-10.41138^{(4)^{*}}$ & $-10.26131^{(4)^{*}}$ & $-8.874331^{(0) *}$ & $-10.39825)^{*} 0($ & $-10.23001^{(0)^{*}}$ & $\mathrm{D}(\mathrm{M} 2)$ \\
\hline & $\begin{array}{l}-1.943563^{(*)} \\
-1.614927^{(* *)}\end{array}$ & $\begin{array}{l}-3.448348^{(*)} \\
-3.149326^{(* *)}\end{array}$ & $\begin{array}{l}-2.886074^{(*)} \\
-2.579931^{(* *)}\end{array}$ & $\begin{array}{l}-1.943563^{(*)} \\
-1.614927^{(* *)}\end{array}$ & $\begin{array}{l}-3.448348^{(*)} \\
-3.149326^{(* *)}\end{array}$ & $\begin{array}{l}-2.886074^{(*)} \\
-2.579931^{(* *)}\end{array}$ & $\begin{array}{l}\text { Test } \\
\text { critical } \\
\text { values }\end{array}$ \\
\hline \multirow[t]{2}{*}{ 1(1) } & $-6.368342^{(4) *}$ & $-6.215071^{(8)^{*}}$ & $-6.300791(6)^{*}$ & $-5.683278^{(2) *}$ & $\left.-6.135607^{2}\right)^{*}($ & $-5.806003)^{* 2(}$ & $\mathrm{D}(\mathrm{EX})$ \\
\hline & $\begin{array}{l}-1.943563^{(*)} \\
-1.614927^{(*)}\end{array}$ & $\begin{array}{l}-3.448348^{(*)} \\
-3.149326^{(* *)}\end{array}$ & $\begin{array}{l}-2.886074(*) \\
-2.579931(* *)\end{array}$ & $\begin{array}{l}-1.943612^{(*)} \\
-1.614897^{(* *)}\end{array}$ & $\begin{array}{l}-3.449020^{(*)} \\
-3.149720^{(* *)}\end{array}$ & $\begin{array}{l}-2.886509^{(*)} \\
-2.580163^{(* *)}\end{array}$ & $\begin{array}{l}\text { Test } \\
\text { critical } \\
\text { values }\end{array}$ \\
\hline \multirow[t]{2}{*}{$1(1)$} & $-10.93364^{(5) *}$ & $11.33721^{(8)^{*}-}$ & $-11.10800^{(6)^{*}}$ & $-4.997387^{(1) *}$ & $-5.051832^{(1) *}$ & $-5.032124) * 1($ & $\mathrm{D}(\mathrm{R})$ \\
\hline & $\begin{array}{l}-1.943563^{(*)} \\
-1.614927^{(*)}\end{array}$ & $\begin{array}{l}-3.448348^{(*)} \\
-3.149326^{(* *)}\end{array}$ & $\begin{array}{l}-2.886074^{(*)} \\
-2.579931^{(* *)}\end{array}$ & $\begin{array}{l}-1.943587^{(*)} \\
-1.614912^{(* *)}\end{array}$ & $\begin{array}{l}-3.448681^{(*)} \\
-3.149521^{(* *)}\end{array}$ & $\begin{array}{l}-2.886290^{(*)} \\
-2.580046^{(* *)}\end{array}$ & $\begin{array}{l}\text { Test } \\
\text { critical } \\
\text { values }\end{array}$ \\
\hline
\end{tabular}

- Source: Outcome from Eviews10.

Notes:- * Indicates the statistical significance.

doi ${ }^{*}: 10.2500$ to the level of $5 \%$.v . $\left.^{* *}\right)$ means the level of $10 \%$, the delay is between the brackets. 
determine the optimal delay period, we proceeded in this step is based on the AICI standard,

within the ARDL model. This standard is an advanced standard in determining the optimal model grade. The grade (p) of the optimal model is tested based on the lowest value of the Eviews-10 standard. The number of deceleration intervals was determined according to the AICI standard and the results were given as $(4,0,0,0$, 0) ARDL.

\subsubsection{Testing for Co- integration}

Table (6) shows the results for the calculation of the statistic (F) of the ARDL (bounds test) method. The calculated $\mathrm{F}$ value of the study sample is higher than the maximum value of the critical values at the level of $1 \%, 5 \%, 10 \%$. The critical values were obtained through the tables presented by, Pasaran et al., (2001), and the following table (6) illustrates the test results as follows:-

Table 6: Results from ARDL bounds test

\begin{tabular}{|l|l|l|l|}
\hline Results & \multicolumn{2}{|l|}{$\begin{array}{l}\text { F-statistic } \\
\text { Calculated }\end{array}$} & Release \\
\hline There is a common & 12.37331 & Sample \\
\cline { 2 - 4 } integration between the & Lowest & highest & $\begin{array}{l}\text { Critical } \\
\text { ralues }\end{array}$ \\
independent variables & rate & rate & valu \\
\cline { 2 - 4 } vith the dependent & 2.45 & 3.52 & $\% 10$ \\
\cline { 2 - 4 } level of 5\% ariable at significant & 2.86 & 4.01 & $\% 5$ \\
\cline { 2 - 4 } & 3.74 & 5.06 & $\% 1$ \\
\hline
\end{tabular}

Source: Outcome from Eviews-10

\subsubsection{Unrestricted Error Correction Model (UECM)}

The results in Table (7) show the short term coefficient of the independent variables of the study and their effect on the stock price index of the Iraqi stock market expressed by the log of the model and the choice of constant . The results of the test showed that the stock price index is affected by the log of consumer price index (LCPI) in the current period by an inverse relationship. The increase in the (LCPI) by one unit lead to a decrease in the stock price index by $(0.59 \%)$. Many economic literature have explained this inverse relationship including (Fama) in providing a different mechanism for this reverse relationship. This mechanism implies that the increase in prices is linked to a direct relationship with the real economic variables (economic activity) and that this economic activity is inversely related to the consumer price index, making the correlation between stock price and consumer price index also inverse (Attiyah, 2012, 20).

The exchange rate for the current period (LEX) did not show a significant relationship with the stock price index in the Iraqi Stock Exchange. This indicates that the stock prices decline as a reaction to the devaluation of the currency. In this case, the shareholder risk will include the combination of currency devaluation and a decline in returns on capital.

As for money supply (LM2), the results of the test showed that there is no significant effect on the stock price index in the current period and this is contrary to the third hypothesis in the short term, as the coefficient of elasticity (LM2) reached (-1.234683) because of the increase in money supply in the form of increase in salaries of employees, investment spending, military spending, as well as the result of the changing of the Iraqi currency after the issuance of the Central Bank Law No. 56 in 2004, and raise the volume of foreign currency reserves of the Central Bank of Iraq against the local currency in order to raise the value of the Iraqi Dinar. The central bank adopted a tight monetary policy to stabilize exchange rates, which contributed to improving the purchasing power of the local currency and general low level of prices.

The interest rate had a significant effect on stock price index in the Iraqi Stock Exchange. The elasticity coefficient (LR) was estimated at (4.396024) with a 


\begin{tabular}{|l|l|l|l|}
\hline \multicolumn{4}{|l}{ Co integrating Form } \\
\hline Variable & Coefficient & t-Statistic & Prob. \\
\hline C & 15.51444 & 0.588522 & 0.5574 \\
\hline LINDEX(-1) & -1.163886 & -7.841948 & 0.0000 \\
\hline LCPI & -0.593278 & -3.911158 & 0.0002 \\
\hline LEX & 0.376111 & 0.137782 & 0.8907 \\
\hline LM2 & -1.234683 & -1.947350 & 0.0541 \\
\hline LR & 4.396024 & 2.620902 & 0.0100 \\
\hline D(LINDEX(-1)) & 0.775879 & 6.126417 & 0.0000 \\
\hline D(LINDEX(-2)) & 0.093347 & 0.929195 & 0.3549 \\
\hline D(LINDEX(-3)) & 0.381998 & 4.120683 & 0.0001 \\
\hline
\end{tabular}

positive sign. The decrease in interest rate by one unit lead to a decrease of in stock prices by $(4.39 \%$ ) with a direct relationship with the stock price index as evident in 2014 when the weighted average interest rates on bank deposits and credit declined by $(0.06 \%)$ compared to 2013 and reaching $(0.14 \%)$ at the end of the year.

The central bank deliberately encourages bank credits by reducing the interest rate to encourage investments. However, foreign investments in the Iraqi Stock Exchange decreased by (30.1) billion Dinars in 2014 compared to (980.2 billion) Dinars in 2013 because of the decline in foreign purchases, which reached (112.5) billion dinars in 2014 compared to (1149.8)billion Iraqi Dinars in 2013, due to the security and economic conditions in Iraq that was reflected in the decline in the stock price index which fell by $(-18.7 \%)$ in 2014, compared to 2013 as it closed at (131.1) points in 2013, compared to (92) points In 2014. التقرير الاقتصادي السنوي لللبنك (ل) Table (7) also shows the results of vector error correction model. The estimated coefficient of the error correction term is statistically significant and negative(-1.163886), implying a rapid adjustment towards long-term equilibrium following a short-run shock. Deviation from the long-run equilibrium is corrected by $(1.16 \%)$ in the current month. This finding indicates a stable long-term relationship among the variables. Furthermore, variables such as consumer prices index and money supply had negative effects on the index, while the effect of exchange rate was non-significant in the shortterm. Besides, a significantly positive short-run relationship is found between interest rate on current deposits and the stock market indices shown in table (7).

\section{Table (7): Short-Run Model Estimates}

Source: Outcome from Eviews-10

\subsubsection{Long- Run Relationship Analysis}

This includes the estimation of the relationship between the independent variables (CPI, EX, 2M, R) for the Iraqi Stock Exchange. Table (8) shows the results of estimating the long term relationship of the study variables (CPI, EX, M2, R). The results of the elastic coefficient (LCPI) which reached (-0.509739) shows that a rise in the index of consumer prices in one unit leads to a decline in stock prices by $(0.50 \%)$. This result is similar to other studies (Chia \&Lim ,2015 :Yaala \& Henchiri,2016: Khalid \& Khan ,2017) as one of the determinants ( consumer price index ) has a significant long-term short-run relationship with stock prices. The reason for the negative sign between the variables is due to the surplus in money supply since 2003 due to the lack of monetary and financial policies resulting in the rise in the level of consumer prices. Besides the unilateral economy has caused dependence on oil export revenues, and the rise of growth rate of service sectors on the expense of the growth rate of goods sectors, which is the main reason why structural and monetary imbalances in the Iraqi economy affected all Iraqi economic activity and led to the decline in 
companies' profits, which lead to a decline in share prices. This result calls for policy makers to focus more on consumer price index to maintain the stability of the stock market.

For the exchange rate (LEX), the results showed that it had a non -significant effect on the stock price index with a positive sign of (0.323151) units. This finding goes with the studies of (Nijam et al, 2015). The reasons for that is the lack of a developed money market in Iraq while the Central Bank of Iraq controls exchange rate of Iraqi currency against the USD thorough daily auctions making the fluctuations in exchange rates not effecting the domestic economy and achieves a relative monetary stability in the country (154، الجنابي،2013 ) .

A significant inverse relationship was found between the money supply (LM2) and the stock price index in the long run as M2 was estimated at ( -1.060828) and prob $(0.0439)$ at $5 \%$. This means that the decline in the supply of money by one unit leads to a rise in stock prices by $(1.06 \%)$ and its sign was identical to the sign in the short-term. This result is similar to studies (Khalid \& Khan, 2017). This is due to the gradual increase in the money supply by the Central Bank of Iraq. The increase in money supply was due to several factors including the increase in money supply in the form of increase in salaries of employees, investment spending, military spending, as well as the result of the changing of the Iraqi currency after the issuance of the Central Bank Law No. 56 in 2004, and raise the volume of foreign currency reserves of the Central Bank of Iraq against the local currency in order to raise the value of the Iraqi Dinar. From another hand (Fama 1981) assumed that there is an inverse relationship between money supply and stock price index, as he illustrates that the increase money supply will lead to inflation and increase the discount rate leading to a fall in stock prices

Interest-Rate-Current Account (Over Draft) (LR) was positive and significant as it was estimated at (3.777023), The decrease in the current deposit rate by one unit contributes to the decrease in share prices by( $3.77 \%)$.This is due to the fact that the banking sector constitutes the highest percentage of the total value of trading volume in the Iraqi

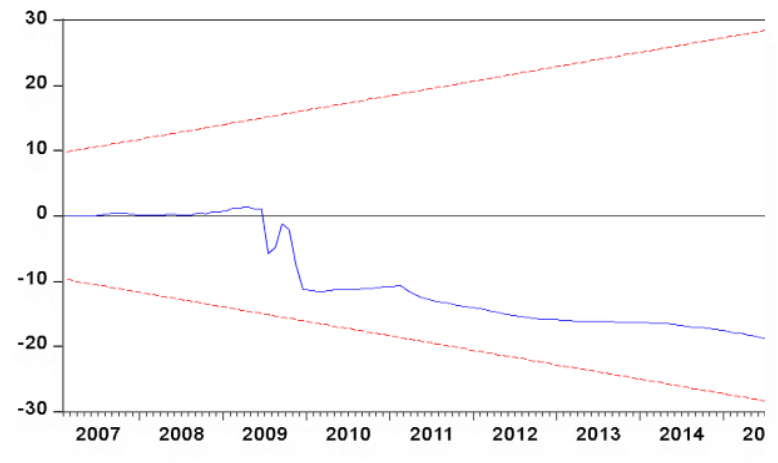
market for securities, with the banking sector accounted for $64.8 \%$ in 2010 , and this percentage rose by $78 \%$ of the total in 2015, followed by the industrial sector and then the hotel sector and tourism, therefore, the central bank has cut interest rates on the future deposits, which reflected negatively on the decline in the volume of circulation of these banks and then the decline in profits and following the decline in market demand on the prices of its shares. (The Annual Report of the Central Bank of Iraq, 2014,30-36), , the table can be followed (8).

Table 8: Long-run ARDL Estimates

Long Run Coefficients

\begin{tabular}{|l|l|l|l|}
\hline Variable & Coefficient & $\begin{array}{l}\mathrm{t}- \\
\text { Statistic }\end{array}$ & \\
\hline LCPI & -0.509739 & -4.710796 & 0.0000 \\
\hline LEX & 0.323151 & 0.137809 & 0.8907 \\
\hline LM2 & -1.060828 & -2.044366 & 0.0434 \\
\hline LR & 3.777023 & 2.818319 & 0.0058 \\
\hline
\end{tabular}

Source: Outcome from Eviews-10

\subsection{7- Stability Test}

The structural static test of the estimated model for the short- and long-term parameters during the duration of 
the study in estimating the ARDAL regression model is achieved through the use of the cumulative sum of the recursive residuals (CUSUM) which is developed by (Brown et al.). If the CUSUM graph falls within the critical area limits at a significant level of $(5 \%)$, in this case the null hypothesis states that all the parameters are stable and acceptable. Despite the fluctuations in the Iraqi economy has negatively impacted his economic activity (Dahmani et al., 2016), Figure (2) shows that the sleep test falls within the critical limits and varies around the zero value. This indicates that the statistical tests confirm the short- and long-term parameters of the ARDAL model for the study sample.

Figure (2) Cumulative total of the model of Iraq ARADL Source: Outcome from Eviews-10

\section{Conclusions and Recommendations}

\subsection{Conclusions}

- Stock markets contribute to the availability of liquidity through their role in facilitating the flow of funds between individuals, institutions, and different sectors. This leads to mobilizing savings and the provision of liquidity to the areas of investment needed in the national economy. The vitality of the stock market lies in the number of registered companies, the volume of securities offered for trading, the number of dealers, and those willing to participate in trading. These factors result in the increase in transactions.

- The results of the study showed that there is a longrun and short-run relationship between a number of macroeconomic variables and the stock price index in the Iraq Stock Exchange (ISX) evident by their co- integration .The long- term relationship showed that (CPI and M2) have a significant impact and inverse relationship with the stock prices index and were estimated at $(-0.509739$, and -1.060828$)$ respectively. The interest rate (R) was estimated at (3.777023) with a positive sign and significant impact on the stock price index, while the exchange rate variable (EX) showed no significance impact on the index. These results match with the short-run results in both significance of the variables and their sign.

- The results of the estimated coefficient of the error correction term for stock price index in the Iraqi Stock Exchange with one period time-lag showed rapid adjustment towards long-term equilibrium by (16.1\%) which means the time required to return to the equilibrium state is two months and sixteen days .

\subsection{Recommendations}

- It is necessary to create an economic climate that promotes general economic stability and supports the activity of companies in the stock market. This can be done by maintaining a secure and stable environment through devising economic policies capable of dealing with unforeseen inflation, preparing the supportive legislative and regulatory frameworks, providing information that increases market efficiency, and focusing on the principles of transparency and disclosure in companies registered in the stock market. These measures may contribute to the safety and integrity of the Iraqi financial market which makes it more attractive to investors from inside and outside the country.

- Keeping pace with the developments of stock markets in developed countries and the latest technologies that facilitate the process of publishing data on companies, volume of trading, prices, pricing methods, and settlements ... etc.

- Expanding the Iraqi Stock Exchange by introducing new sectors into the financial market such as private health, private education, airline 
companies, religious tourism companies, and religious trusts funds. This will contribute to increasing expanding the stock market and increasing national investments.

- The study recommends that decision makers encourage further research on the subject of investment and the utilizing stock markets by introducing other variables to the sample of this study in order to identify the factors affecting the stock prices index such as oil prices and industrial production.

\section{References}

$$
1.6
$$$$
\text { 1.1.6 }
$$

.2014

$$
\text { 1 } 1
$$
https://cbi.iq/news/section/4

2.1.6

1. ادريوش ، دحاني محمد، و بلقايدي، سعدية، وبن قانة ، اساعيل ، ( 2016) ،دراسة انتقال روؤس الاموال الدولية في إطار العلاقة بين الأستثار والأدخار في دول المغرب العربي- دراسة قياسية للفترة (2015-1980)، بجلة الدراسات الاقتصادية الكمية ، 2 (2)، ص. 177-189. البنال، احمد حسين، ومطر،سراب عبد الكريم، 2017، اثر التضخم على عوائد اسهم قطاعات سوق

العراق للاوراق المالية : تحليل نموذج الأندار الذاتي ذو الابطاء الموزعة للمدة 2005-2015، مجلة جامعة الاسلامية للدراسات الاقتصادية والإدارية ، العدد2، ص، 117-96. الجنابي،نييل هدي، (2013) ، كفاءة سوق العراق للاوراق المالية والسياسية النقدية : دراسة قياسية للمدة (2006 -2012)، مجلة القادسية للعلوم الإدارية والأقتصادية ، العدد 3،ص157-131. الزبيدي ،سالم رشيد،والعمدوري ،عامر عمران، (2013)،اثر تقلبات اسعار الصرف في المؤشر العام لاسعار الاسهم دراسة تطبيقة- في سوق العراق للاوراق المالية للمدة 2005-2011، مجلة الإدارة والأقتصاد ، جامعة كبلاء، المجلد 3 ، العدد12، ص157-129. السواعي، خالد محد ، (2015)، أثر تحرير التجارة والتطور الملالي على النمو الأقتصادي - دراسة حالة الاردن - المجلة الاردنية للعلوم الاقتصادية، المجلد 2،العدد 1، ص. 18- 32. 6. عطية ، محمود صاح، (2012)، تحليل العوامل الموضوعية الموثرة في سوق الاوراق المالية عع الاشارة الى سوق العراق، مجلة ديالى ، العدد 54، ص. 1- 35. العنبزي، وسام حسين، 2015، قياس كفاءة سوق العراق للأوراق المالية في ظل التحولات الأقتصادية، بملة جامعة الانبار للعلوم الاقتصادية والإدارية، العدد 14، المجلد 7، ص. 19-40.
النيف، خالد لافي ، (2018)، العلاقة الديناميكية بين متغيرات الاقتصاد الكلي والمؤشر العام لبورصة

عان للاوراق المالية ، المجلة الاردنية للعلوم الاقتصادية ، العدد 2، ص،149-127 .

6.2 English References

6.2.1 Official Publication

1- Annual Reports of the Iraqi Stock Exchange, 20042016, Iraq. http://www.isx-iq.net .

2- Iraqi Securities Commission, (2011), Annual Report on Traffic in Iraq Stock Exchange, Research and Studies Department, Iraq. http://www.isc.gov.iq/node/74.

3- _Iraqi Securities Commission, Annual Reports on Traffic in the Iraqi Stock Exchange, Department of Research and Studies, 2004-2016, Department of Studies and Research, Iraq.

6.2.2 Thesis

1. Talla, T.(2013). Impact of Macroeconomic Variables on the Stock Market Prices of the Stockholm Stock Exchange (OMXS30). Master's Thesis within International Financial Analysis, Jönköping International Business School. http://www.divaportal.org/smash/get/diva2:630705/FULLTEXT0 2 .

6.2.3 Periodicals

1. Barakat,M.Elgazzar,A. And Hanafy,K.(2016), Impact of Macroeconomic Variables on Stock Markets: Evidence from Emerging Markets, International Journal of Economics and Finance; Vol. 8, No. 1,pp 195-205.

2. Chia,R.and Lim,sh.(2015), Malaysian Stock Price And Macroeconomic Variables: Auto Regressive Distrlbuted Lag(ARDL) BoUunds Test, Kajian Malaysia, Vol. 33, No.1,pp, 85-103.

3. Gay,R.(2008). Effect Of Macroeconomic Variables On Stock Market Returns For Four Emerging Economies: Brazil, Russia, India, And China. 
International Business \& Economics Research Journal ,No 7, pp,1-8.

4. Khalid,W.and Khan,S.(2017). Effects of Macroeconomic Variables on the Stock Market Volatility The Pakistan Experience. Global Journal of Management and Business Research, No. 17 ,pp,1-25.

5. Ngos, Le Khanh .,and Hussainey, Khaled.(2009).

The Impact of Macroeconomic Indicators On Vietnamese stock prices, The Journal of Risk Finance, Vol.10, No. 4, pp. 321-332.

6. Nijam,H. Ismail,S. And Musthafa,A.(2015), The Impact of Macro-Economic Variables on Stock Market Performance; Evidence From Sri Lanka , Journal of Emerging Trends in Economics and Management Sciences, No.2,pp,151-157.

6.2.4 Internet

1. Patel,S.(2012). The effect of Macroeconomic Determinants on the Performance of the Indian Stock Market,Journal of NMIMS Management Review,http://www.nmims.edu/NMIMSmanage mentreview. 